JEMMA (Jurnal of Economic, Management, and Accounting)

p-ISSN : 2615-1871/ e-ISSN : 2615-5850

http://www.ojs.unanda.ac.id/index.php/jemma/index

\title{
Analisis Media Promosi Produk Ritel Dalam Meningkatkan Penjualan Pada Toko "Dika” Dusun Krapyak Kulon Kelurahan Panggungharjo Kecamatan Sewon Kabupaten Bantul Daerah Istimewa Yogyakarta
}

\author{
Sumarwanto ${ }^{1^{*}}$

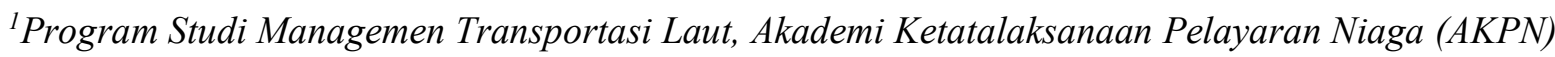 \\ "Bahtera" Yogyakarta \\ a.Email: sumarwanto2603@gmail.com
}

\section{Article History:}

Received: 10-02-2021; Received in Revised: 16-02-2021; Accepted: 26-02-2021

DOI: http://dx.doi.org/10.35914/jemma.v4i1.651

\begin{abstract}
Abstrak
Dalam perdagangan besar produk yang dijual beraneka ragam, membutuhkan modal yang cukup besar serta relasi yang cukup banyak. Pedagang besar biasa disebut dengan perdagangan secara grosir yang tidak menjual barang dagangannya dalam jumlah kecil tetapi pada jumlah yang besar atau tidak diecer. Ketatnya persaingan pedagang besar dan pedagang kecil, pasar tradisional,pada pasar modern menjadi suatu bumerang yang sangat besar pengaruhnya pada kebudayaan ekonomi. Toko "DIKA" adalah toko kelontong yang menjual produk ritel yang dibutuhkan masyarakat dalam memenuhi kebutuhan sehari-hari. Dalam penelitian ini menggunakan metode komparatif. Penelitian ini dilaksanakan Pada Toko Ritel "Dika" Krapyak Yogyakarta. Waktu Penelitian dilaksanakan pada Bulan Agustus sampai dengan September 2018. Analisis yang digunakan adalah data penjualan selama 5 tahun. Hasil penelitian menunjukan perbandingan pemakaian media promosi selama 5 tahun rata-rata hasil penjualan menggunakan promosi sebesar 24,800,000 lebih besar dibandingkan sebelum menggunakan promosi sebesar 22,483,333. Artinya media promosi dapat meningkatkan hasil penjualan. Media handphone dan Koran merupakan alat promosi yang tepat untu meningkatkan hasil penjualan.
\end{abstract}

Kata Kunci: Analisis, Media Promosi, Toko Dika

\begin{abstract}
In a large trade, various products are sold, requiring a large enough capital and quite a lot of relationships. Wholesalers are usually called wholesale trading which does not sell their merchandise in small quantities but in large quantities or not at retail. The intense competition between wholesalers and small traders, traditional markets, in modern markets has become a boomerang which has a very large impact on economic culture. The "DIKA" shop is a grocery store that sells retail products that are needed by the community to meet their daily needs. In this study using a comparative method. This research was conducted at the Retail Store "Dika" Krapyak Yogyakarta. Research time was conducted from August to September 2018. The analysis used was
\end{abstract}


sales data for 5 years. The results showed the comparison of the use of promotional media for 5 years, the average sales result using the promotion was 24,800,000 greater than before using the promotion which was 22,483,333. This means that promotional media can increase sales results. Mobile and newspaper media are the right promotional tools to increase sales results.

Keywords: Analysis, Promotional Media, Toko Dika

\section{Pendahuluan}

Dalam dunia bisnis Perdagangan dibagi menjadi dua tipe yaitu perdagangan kecil dan pedagang besar (malinda, 2016). Pedagang besar merupakan kegiatan yang terlibat dalam penjualan barang atau jasa kepada orang-orang yang membelinya untuk dijual kembali atau untuk penggunaan bisnis (Cahyadin dkk, 2017). Adapun contoh perdaganan besar yaitu Lottemart, Carefour, Mitra grosir, dan toko-toko kelontong yang menjual secara grosir. Sedangkan pedagang kecil atau eceran (Retailing) adalah kegiatan yang tercakup dalam penjualan barang atau jasa langsung kepada konsumen akhir untuk penggunaan pribadi dan non-bisnis (Utami, 2018). Adapun contohnya Alfamart, Indomart dan Peritel lain yang langsung pada end user atau konsume akhir.

Dalam perdagangan besar produk yang dijual beraneka ragam, membutuhkan modal yang cukup besar serta relasi yang cukup banyak (Iskandar, 2017). Pedagang besar ini juga biasa disebut dengan perdagangan secara grosir yang tidak menjual barang dagangannya dalam jumlah kecil tapi dihadapkan pada jumlah yang besar atau tidak diecer. Seperti yang kita ketahui barang dagangan yang biasanya dijual oleh pedagang besar dapat berupa makanan, sembako, pakaian, elektronik, obat-obatan, aksesoris, alat-alat rumah tangga, kain, dan masih banyak lagi. Pedagang besar juga dapat memilih kelompok sasaran berdasarkan ukuran pelanggan (hanya pengecer besar), berdasarkan jenis pelanggan (hanya toko makanan sehari-hari), kebutuhan akan layanan (para pelanggan yang membutuhkan kredit) atau faktorfaktor lainnya (Utami, 2018). Dalam berkarir promosi meningkatkan tingkat penjualan barang ritel, Sedangkan dalam pemasaran, promosi merupakan memajukan pertumbuhan animo baik itu produk maup, merek, ataupun perusahaan.

Persaingan dan tantangan bagi para pedagang besar yaitu adanya bisnis waralaba (Inas Fahmiyah, 2019). Supermarket dan minimarket waralaba banyak menjamur diberbagai kota kecil dan kota-kota besar di Indonesia dari yang menjual secara grosir maupun ritel (eceran), Ketatnya persaingan pedagang besar dan pedagang kecil, perbedaan antara pasar modern dan pasar tradisonal terbagi menjadi suatu 2 bumerang yang sangat besar pengaruhnya pada kebudayaan ekonomi diberbagai faktor usaha (Pramudiana, 2017). Apalagi sekarang ini pasar pedagang besar/kecil modern hadir dengan penampilan yang lebih baik, bersih, bentuk bangunannya bagus atau menarik, nyaman, pelayanan yang baik, harga terkendali, buka 24 jam non stop, bahkan ada yang mengkombinasikannya dengan hiburan dan pusat pembelanjaan fasionable serta foodcourt, dan sederet tawaran menarik lainnya. Hal ini tentu saja menjadi ancaman besar bagi para pedagang besar/kecil tradisional yang penampilannya hanya sebatas bangunan toko yang terbatas ruang gerak usahanya, dan dipasar tradisional yang kita tahu dan kita lihat adalah pasar yang kumuh,becek, bejubel, kotor, harga yang sering dmainkan seenaknya dan lain sebagainya. Adapun penelitian ini dilakukan untuk melihat keefektifan dalam berpromosi dari Handphone, Koran, Radio maupun brosur. 
Kebanyakan pedagang besar belom memperhatikan sadar akan pentingnys promosi, tetapi sebagian dari pedagang besar menggunakan strategi promosi yang terdiri dari pemberian sample pada suatu produk baru maupun inovasi produk baru (Hedynata \& Radianto, 2016). Para pedagang besar menyimpan persediaan barang yang beranekaragam, dikarenakan untuk mengurangi resiko kehabisan barang pada saat dibutuhkan, karena sering kali pembelian yang dilakukan oleh konsumen adalah pembelian yang tidak direncanakan (impulsive buying) akibatnya adanya pengaruh bauran pemasaran dari perusahaan (Yusuf \& Rangkuty, 2019). Menurut (Amaliati, 2017) pembelian tidak direncanakan terjadi karena impulsif semata, impulsif karena timbul kebutuhan (suggestion impulse), dan impulsif yang direncanakan. Keputusan pemembelian produk ditentukan ketika pembili di toko pada saat melihat-lihat barang/produk yang tersedia. Promosi (promotion) dengan cara: Spanduk, dengan menuliskan penawaran-penawaran yang persuasive dengan huruf yang menonjol serta menampilkan nomor telepon yang dihubungi, spanduk tersebut dipasang pada lokasi yang strategis, Brosur, memberikan headline yang menarik dan memberikan keuntungan bagi pembacanya, Papan penunjuk arah, dijadikan sebagai penunjuk arah dimana unit pelayanan cabang atau cabang induk berada, yang dipasang dilokasi (Pagiu, 2019).

Toko "DIKA" adalah toko kelontong yang menjual produk ritel yang dibutuhkan masyarakat dalam memenuhi kebutuhan sehari-hari. Keberadaan toko "DIKA" mengacu pada kebutuhan hajat hidup masyarakat Banyak yang memerlukan produk ritel untuk dikonsumsi secara langsung baik siang maupun malam. Hal inilah yang menjadikan Toko "DIKA" menggeluti ritel sebagai komoditi bisnis yang menjanjikan baik sekarang maupun dimasa yang akan datang. Bisnis ritel merupakan keseluruhan aktivitas bisnis yang terkait dengan penjualan dan pemberian layanan kepada masyarakat sebagai konsumen untuk penggunaan yang sifatnya individu sebagai pribadi maupun keluarga. Keberhasilan pasar ritel yang kompetitif, pelaku ritel harus dapat menawarkan produk yang tepat, dengan harga, waktu dan tempat yang tepat pula (Mukaram \& Sarah, 2017). Oleh karena itu, pemahaman terhadap pelaku ritel terhadap karakteristik dan target pasar atau konsumen yang akan dilayani merupakan hal yang sangat penting. Dalam operasionalnya toko "DIKA" menjalankan beberapa fungsi antara lain membantu konsumen dalam menyediakan berbagai produk dan jasa serta memecah maupun menambah nilai produk.

Berdasarkan latar belakang masalah tersebut pada penelitian ini bertujuan untuk menganalis dan mengetahui promosi penjual produk ritel dengan berbagai macam media promosi dari handphone, brosur, koran, radio. Selain itu pada penelitian ini juga menganalisi media promosi yang cocok untuk meningkatkan penjualan produk ritel pada toko Dika.. Dalam penelitian ini diharapkan dapat merumuskan media promosi yang efektif dan tepat dalam penjualan ritel pada Toko Dika yang mengkomonikasikan suatu produk/jasa/ image/ perusahaan ataupun yang lain untuk dapat lebih di kenal masyarakat lebih luas.

\section{Metodologi}

Penelitian ini dilaksanakan Pada Toko Ritel "Dika" beralamat J1. K.H. Ali Maksum Dusun Krapyak Kulon Kelurahan Panggungharjo Kecamatan Sewon Kabupaten Bantul Daerah Istimewa Yogyakarta. Adapun jenis data yang digunakan adalah data primer yang diambil dari toko Dika selama 5 tahum. Penelitian ini dilaksanakan pada bulan Agustus 
sampai dengan September 2018. Teknk pengumpulan data dilakukan dengancara wawancara yang diperoleh dari pemilik toko dan manager penjual Toko Dika. Jenis penelitian ini menggunakan metode komparatif. Dengan menggunakan metode komparatif penulis bermaksud untuk menarik sebuah kesimpulan berdasarkan Perbandingan, ide-ide dan pendapat Menurut (T Kasim, 2014) Penelitian komparatif adalah penelitian yang ingin mencari jawaban secara mendasar tentang sebab akibat dengan menganalisis faktor-faktor penyebab terjadinya ataupun munculnya fenomena tertentu. Jenis penelitian komparatif ini digunakan untuk membandingkan dua kelompok atau lebih dari suatu variable tertentu. Penelitian komparatif bersifat expost facto artinya data yang dikumpulkan setelah peristiwa yang dipermasahkan terjadi (Falah \& Suparmin, 2016).

Expost facto merupakan suatu penelitian empiris yang sistematis dimana peneliti tidak mengendalikan variable bebas secra langsung karena perwujudan variable tersebut telah terjadi atau karena variable tersebut pada dasarnya tidak dapat dimanipulasi (Saputra dkk., 2016). Dalam hal ini, Peneliti tidak melakukan perlakuan dalam membandingkan dan mncari hubungan sebab akibat dari variabelnya, peneliti hanya mancari satu atau lebih akibat-akibat yang ditimbulan dari mengujinya dan menelusuri kembali masa lalu untuk mencari sebabsebab kemingkinan hubungan dan maknanya seperti pada uraian pendahuluan. Dalam Penelitian ini, data yang dipergunakan adalah data primer dan data skunder, yang bersifat kualitatif yaitu penjabaran dari konsep dan landasan teori yang sudah dijabarkan pada bab bab sebelumnya, maupun kuantitatif yaitu data yang berasal dari jawaban responden yang diolah dan mendapatkan hasil untuk dianalisa misalnya diagram kartesius. Pengertian data primer adalah data yang diperoleh secara langsung dari obyek penelitian, sedangkan data skunder adalah data yang diperoleh tidak secara langsung dari sumbernya malainkan melaui sumber kepustakaan.

Dalam penelitian ini data diperoleh dengan menggunakan metode pengumpulan data yaitu dengan cara Observasi, Wawancara, Dokumentasi. Adapun observasi dilakukan dengan melihat perilaku dan kinerja pegawai (sumber daya manusia) yang berjumlah 10 orang. Wawancara dilakukan terhadap responden yang berjumlah 8 orang. Renponden tersebut tersebut terdiri dari unsur-unsur top manajemen,

Metode analisa data dalam penelitian ini yaitu penentuan masalah penelitian ada tahap perumusan masalah penelitian atau pertanyaan penelitian, peneliti berspekulasi dengan apa yang menjadi penyebab fenomena yang berdasarkan pada hasil penelitian sebelumnya, teori, atau pengamatan langsung. Penentuan kelompok yang mempunyai karakteristik yang akan diteliti. Peneliti harus menentukan kelompok yang seperti apa yang akan diteliti disesuaikan dengan isu atau masalah yang akan diangkat. Pemilihan kelompok pembanding. Setelah memperoleh kelompok yang akan diteliti langkah berikutnya memilih kelompok pembanding dengan mempertimbangkan karakteristik yang membedakan dengan kelompok penelitian. Kelompok ini harus dideskripsikan secara jelas dan didefinisikan secara operasional untuk masing-masing kelompok yang mewakili populasi yang berbeda. Tidak lupa untuk mengontrol variabel ekstra guna membantu menjamin kesamaan kedua kelompok. Dalam tahap pengumpulan data dilakukan dengan menggunakan instrumen penelitian yang harus memenuhi persyaratan validitas dan realibilitas. Analisis data Pada tahap terakhir yaitu analisis data, analisis data dimulai dengan analisis statistik deskriptif yaitu menghitung ratarata dan simpangan baku. Kemudian dilakukan analisis yang mendalam dengan statistik 
inferensial. Teknik yang dapat digunakan sebagai analisis data dalam penelitian menggunakan metodologi komparatif dengan teknik penyajian data kualitatif.

\section{Hasil dan Pembahasan}

Toko kelontong "DIKA" merupakan toko yang menyediakan produk ritel guna memenuhi kebutuhan masyarakat sebagai konsumen akhir yang langsung menggunakan produk tersebut. Keberadaan toko kelontong "DIKA" di Jl. KH. Ali Maksum Krapyak Kulon Bantul Yogyakarta berada di lingkungan masyarakat yang majemuk, karena masyarakat di sekitar tempat tersebut adalah masyarakat yang datang dari seluruh pelosok di Indonesia. Aktivitas masyarakat di wilayah Krapyak yang padat dengan berbagai akifitas menjadikan tempat tersebut terjadi aktifitas dalam kurun waktu 24 jam. Inilah yang menjadikan toko kelontong "DIKA" selalu berkomitmen melayani kebutuhan masyarakat.

Media promosi yang selama ini digunakan toko dika meliputi Radio, Brosur, Handphone dan Koran. Radio merupakan salah satu alternative pilihan yang dipergunakan oleh toko dika karena memiliki pendengar dari berbagai kalangan, dalam kondisi apapun, radio menjadi sarana bagi pendengar untuk memperoleh informasi yang terbaru. Hal inilah yang menjdi tujuan dalam mempromosikan produk ritel.

Kedua adalah Brosur dalam mempromosikan produk ritel, toko dika menggunakan brosur untuk menjangkau konsumen secara langsung. Dalam hal ini penggunaan media brosur disertai gambar produk sekalgus harga produk serta desian yang menarik. Hal ini bertujuan untuk menarik minat konsumen agar, pembeli produk ritel yang dijual toko dika.

Ketiga adalah Handphone Merupakan alat telekomunikasi elektronik dua arah yang bisa dibawa kemana-mana dan memiliki kemampuan untuk mengirimkan pesan berupa suara. Dalam keseharian kini manusia hampir tidak bisa lepas dari handphone. Apalagi dengan semakin berkembangnya handphone sehingga handphone memiliki berbagai fungsi sekaligus. Bukan hanya sebagai alat komunikasi saja namun telah berkembang menjadi alat dengan fungsi lainnya seperti sebagai media hiburan, media bisnis, dan sebagainya. Peluang inilah yang dimanfaatkan toko dika untuk mempromosikan produk ritel.

Keempat adalah Koran dalam mepromosikan produk ritel, toko dika menggunakan media koran dengan pertimbangan bahwa koran adalah sejenis media massa yang memberitakan kejadian-kejadian sehari-hari dalam kehidupan manusia. Dengan menggunakan media Koran konsumen dapat membaca Tulisan-tulisan yang terdapat didalamnya termasuk produk ritel yang dipromosikan toko Dika. Berikut tabel yang menggambarkan jumlah penggunaan media promosi pada toko dika dapat dilihat pada Tabel 1 berikut.

Tabel 1. Penggunaan Media Promosi Toko Dika Dalam Kurun Waktu 5 Tahun

\begin{tabular}{lcccccc}
\hline \multicolumn{1}{c}{ Media } & \multicolumn{7}{c}{ Tahun } \\
\cline { 2 - 7 } \multicolumn{1}{c}{ Promosi } & 2013 & 2014 & 2015 & 2016 & 2017 & Ket \\
\hline Radio & - & - & - & - & V & 1 kali \\
\hline Brosur & - & - & - & V & V & 2 kali \\
\hline Handphone & - & - & V & V & V & 3 kali \\
\hline Koran & - & - & V & V & V & 3 kali \\
\hline
\end{tabular}




\section{Perhitungan Pengambilan Laba Produk Ritel}

Daftar kelompok produk ritel yang dijual di Toko Dika JL.KH.Ali Maksum No.11 Krapyak Kulon Yogyakarta dapat dilihat pada tabel sebagai berikut:

Tabel 2. Kelompok Produk Ritel Yang Dijual di Toko Dika

\begin{tabular}{cll}
\hline No. & \multicolumn{1}{c}{ Kelompok Produk } & Produksi \\
\hline 1. & Rentengan & Pabrikan \\
\hline 2. & Rokok & Pabrikan \\
\hline 3. & Snack & Pabrikan \\
\hline 4. & Aneka minuman (Botolan / Kalengan) & Pabrikan \\
\hline 5. & Sembako & Pabrikan \\
\hline 6. & Plastik & Pabrikan \\
\hline 7. & Rupa-rupa & Pabrikan \\
\hline 8. & Unilever & Pabrikan \\
\hline 9. & Obat-obatan generic & Pabrikan \\
\hline 10. & Kerajinan & Rumahan \\
\hline
\end{tabular}

Tabel 3. Perhitungan Pengambilan Laba Produk Ritel Pada Toko Dika

\begin{tabular}{|c|c|c|c|c|}
\hline No. & Jenis produk & Produksi & Laba $(\%)$ & Keterangan \\
\hline 1. & Rentengan & Pabrikan & 15 & \multirow{11}{*}{$\begin{array}{l}\text { Pengambilan } \\
\text { nilai } \\
\text { laba kotor } \\
\text { berda } \\
\text { sarkan } \\
\text { pengamatan } \\
\text { harga pasaran }\end{array}$} \\
\hline 2. & Rokok & Pabrikan & 5 & \\
\hline 3. & Snack & Pabrikan & 20 & \\
\hline 4. & Aneka minuman (Botolan / Kalengan) & Pabrikan & 15 & \\
\hline 5. & Sembako & Pabrikan & 10 & \\
\hline 6. & Plastik & Pabrikan & 12 & \\
\hline 7. & Rupa-rupa & Pabrikan & 20 & \\
\hline 8. & Unilever & Pabrikan & 10 & \\
\hline 9. & Obat-obatan generic & Pabrikan & 12 & \\
\hline 10. & Kerajinan & Rumahan & 20 & \\
\hline & Laba rata -rata & & 13,9 & \\
\hline
\end{tabular}

Tabel 4. Peningkatan Hasil Penjualan Produk Ritel pada Toko Dika selama 5 Tahun Setelah Menggunakan Media Promosi

\begin{tabular}{rlrr} 
No. & \multicolumn{1}{c}{ Jenis produk } & $\begin{array}{c}\text { Sebelum promosi } \\
(\mathrm{Rp})\end{array}$ & $\begin{array}{c}\text { Sesudah Sebelum } \\
(\mathrm{Rp})\end{array}$ \\
\hline 1. & Rentengan & 134.900 .000 & 148.800 .000 \\
\hline 2. & Rokok & 123.400 .000 & 137.300 .000 \\
\hline 3. & Snack & 134.900 .000 & 155.900 .000 \\
\hline 4. & Aneka minuman (Botolan / Kalengan) & 116.100 .000 & 126.100 .000 \\
\hline 5. & Sembako & 165.600 .000 & 225.800 .000 \\
\hline 6. & Plastik & 163.900 .000 & 176.500 .000 \\
\hline 7. & Rupa-rupa & 134.500 .000 & 145.600 .000 \\
\hline 8. & Unilever & 136.100 .000 & 115.800 .000 \\
\hline 9. & Obat-obatan generic & 124.300 .000 & 127.800 .000 \\
\hline 10. & Kerajinan & 115.300 .000 & 128.400 .000 \\
\hline
\end{tabular}




\section{Analisa Data}

Tabel 5. Data Sebelum Dan Sesudah Pemakaian Media Promosi

\begin{tabular}{|c|c|c|c|c|c|}
\hline \multicolumn{6}{|c|}{$\begin{array}{l}\text { Penjualan (Dalam } 5 \text { tahun) } \\
\text { tanpa menggunakan promosi }\end{array}$} \\
\hline \multirow{2}{*}{ Bulan } & \multicolumn{5}{|c|}{ Tahun } \\
\hline & 2013 & 2014 & 2015 & 2016 & 2017 \\
\hline Januari & 18.000 .000 & 19.000 .000 & 20.000 .000 & 19.000 .000 & 21.000 .000 \\
\hline Februari & 20.000 .000 & 21.000 .000 & 22.000 .000 & 23.000 .000 & 23.500 .000 \\
\hline Maret & 19.000 .000 & 21.000 .000 & 20.000 .000 & 20.500 .000 & 22.000 .000 \\
\hline April & 20.500 .000 & 22.500 .000 & 24.500 .000 & 25.500 .000 & 25.500 .000 \\
\hline Mei & 18.900 .000 & 19.900 .000 & 19.900 .000 & 20.900 .000 & 21.900 .000 \\
\hline Juni & 19.500 .000 & 20.500 .000 & 22.500 .000 & 23.500 .000 & 24.500 .000 \\
\hline Juli & 20.000 .000 & 23.000 .000 & 24.000 .000 & 25.000 .000 & 27.000 .000 \\
\hline Agustus & 21.000 .000 & 22.000 .000 & 24.000 .000 & 25.000 .000 & 26.000 .000 \\
\hline September & 19.400 .000 & 19.400 .000 & 20.400 .000 & 21.400 .000 & 22.400 .000 \\
\hline Oktober & 20.100 .000 & 22.100 .000 & 24.100 .000 & 25.100 .000 & 26.100 .000 \\
\hline November & 21.200 .000 & 23.200 .000 & 25.200 .000 & 26.200 .000 & 28.200 .000 \\
\hline Desember & 20.000 .000 & 24.000 .000 & 26.000 .000 & 28.000 .000 & 30.000 .000 \\
\hline total & 237.600 .000 & 257.600 .000 & 272.600 .000 & 283.100 .000 & 298.100 .000 \\
\hline \multicolumn{6}{|c|}{ Penjualan (Dalam 5 tahun) } \\
\hline \multicolumn{6}{|c|}{ Setelah menggunakan media Promosi } \\
\hline \multirow{2}{*}{ Bulan } & \multicolumn{5}{|c|}{ Tahun } \\
\hline & 2013 & 2014 & 2015 & 2016 & 2017 \\
\hline Januari & 18.000 .000 & 19.000 .000 & 24.000 .000 & 28.000 .000 & 33.000 .000 \\
\hline Februari & 20.000 .000 & 21.000 .000 & 24.000 .000 & 27.000 .000 & 29.500 .000 \\
\hline Maret & 19.000 .000 & 21.000 .000 & 25.000 .000 & 24.500 .000 & 28.000 .000 \\
\hline April & 20.500 .000 & 22.500 .000 & 26.500 .000 & 29.500 .000 & 29.500 .000 \\
\hline Mei & 18.900 .000 & 19.900 .000 & 22.900 .000 & 25.900 .000 & 27.900 .000 \\
\hline Juni & 19.500 .000 & 20.500 .000 & 25.500 .000 & 28.500 .000 & 29.500 .000 \\
\hline Juli & 20.000 .000 & 23.000 .000 & 24.000 .000 & 25.000 .000 & 33.000 .000 \\
\hline Agustus & 21.000 .000 & 22.000 .000 & 24.000 .000 & 30.000 .000 & 30.000 .000 \\
\hline September & 19.400 .000 & 19.400 .000 & 20.400 .000 & 25.400 .000 & 27.400 .000 \\
\hline Oktober & 20.100 .000 & 22.100 .000 & 24.100 .000 & 30.100 .000 & 30.100 .000 \\
\hline November & 21.200 .000 & 23.200 .000 & 25.200 .000 & 30.200 .000 & 32.200 .000 \\
\hline Desember & 20.000 .000 & 24.000 .000 & 26.000 .000 & 32.000 .000 & 35.000 .000 \\
\hline Total & 237.600 .000 & 257.600 .000 & 291.600 .000 & 336.100 .000 & 365.100 .000 \\
\hline
\end{tabular}

1. Hasil Uji Normalitas

Uji normalitas dilakukan untuk mengeahui apakah suatu data berdistribusi normal atau tidak. Hasil uji normalitas dalam penelitian ini disajikan pada Tabel 6 berikut: 
Tabel 6. Uji Normalitas Data Penjualan

\begin{tabular}{crc}
\hline Tahun & P-Value & Keterangan \\
\hline 2013 & 0,472 & Normal \\
2014 & 0,779 & Normal \\
2015 & 0,076 & Normal \\
2016 & 0,911 & Normal \\
2017 & 0,956 & Normal \\
\hline
\end{tabular}

Tabel 6 diperoleh hasil uji normalitas data yang berdistribusi normal baik pada data tahun 2013 dengan nilai signifikansi 0,472 >0,05, data tahun 2014 dengan nilai signifikansi $0,779>0,05$, data tahun 2015 dengan nilai signifikansi $0,076>0,05$, data tahun 2016 dengan nilai signifikansi $0,991>0,05$ dan data tahun 2017 dengan nilai signifikansi 0,95 Berdasarkan hasil uji normalitas diatas maka data dianalisis menggunakan Paired T-test karena data terdistribusi normal.

2. Hasil Uji Perbandingan Hasil Penjualan

Dari penelitian yang dilakukan diperoleh perbandingan hasil penjualan yang didapatkan dengan menggunakan media promosi dan tanpa menggunakan media promosi pada tabel di bawah ini:

Tabel 7. Perbandingan hasil penjualan dengan promosi dan tanpa promosi tahun 2013-2017

\begin{tabular}{clccc}
\hline \multicolumn{2}{c}{ Variabel } & N & Mean & P-value \\
\hline Hasil & Sebelum $*$ & 60 & 22483333 & 0,000 \\
Penjualan & Sesudah & \multicolumn{4}{c}{24800000} \\
\hline Tabel 7 didapatkan hasil Paired & T-test & sebesar $0,000<0,05$, sehingga dapat
\end{tabular}
disimpulkan bahwa terdapat perbedaan hasil penjualan sebelum menggunakan promosi dan sesudah menggunakan promosi. Didukung perolehan nilai rata-rata hasil penjualan sebelum menggunakan promosi sebesar 24,800,000 lebih besar dibandingkan sebelum menggunakan promosi sebesar 22,483,333. Hasil tersebut dapat dirtinya media promosi dapat meningkatkan hasil penjualan. Berdasarkan hasil tersebut dapat digunakan sebagai solusi untuk meningkatakan hasil penujualn dapat meimplementasi media promosi yang ada, seperti media promosi melaui radio, brosur, handphone dan koran. Target media promosi yang paling tepat digunakan adan handpone dan koran yang setiap saat orang menggunakan media tersebut untuk aktifitas. Perbandingan hasil penjualan dengan promosi dan tanpa promosi pertahun dijabarkan lebih lanjut pada tabel 8 sebagai berikut:

Tabel 8. Perbandingan Hasil Penjualan dengan Promosi dan Tanpa Promosi Tahun 2013

\begin{tabular}{cllcc}
\hline \multicolumn{2}{c}{ Variabel } & N & Mean & P-value \\
\hline Hasil Penjualan & Sebelum $*$ & 12 & $19,800,000$ & 1,000 \\
Tahun 2013 & Sesudah & & $19,800,000$ & \\
\hline
\end{tabular}


Tabel 8 diperoleh nilai $\mathrm{p}$ value sebesar $1,000>0,05$, artinya tidak terdapat perbandingan hasil penjualan pada tahun 2013 baik dengan promosi maupun tanpa promosi. Hal tersebut diperkuat dengan rata-rata perolehan hasil penjualan yang sama yaitu sebesar 19,800000 baik sebelum maupun sesudah menggunakan media promosi.

Tabel 9. Perbandingan Hasil Penjualan dengan Promosi dan Tanpa Promosi Tahun 2014

\begin{tabular}{cllcc}
\hline \multicolumn{2}{c}{ Variabel } & N & Mean & P-value \\
\hline Hasil Penjualan & Sebelum $*$ & 12 & $21,466,666$ & 1,000 \\
Tahun 2014 & Sesudah & & $21,466,666$ & \\
\hline
\end{tabular}

Berdasarkan tabel 9 diperoleh nilai $\mathrm{p}$ value sebesar $1,000>0,05$, artinya tidak terdapat perbandingan hasil penjualan pada tahun 2014 baik menggunakan promosi maupun tidak menggunakan promosi. Hal tersebut diperkuat dengan rata-rata perolehan hasil penjualan yang sama sebesar $21,466,666$ baik sebelum maupun sesudah menggunakan media promosi.

Tabel 10. Perbandingan Hasil Penjualan dengan Promosi dan Tanpa Promosi Tahun 2015

\begin{tabular}{cllcc}
\hline \multicolumn{2}{c}{ Variabel } & N & Mean & P-value \\
\hline Hasil Penjualan & Sebelum $*$ & 12 & $22,716,666$ & 0,057 \\
Tahun 2015 & Sesudah & & $24,300,000$ & \\
\hline
\end{tabular}

Tabel 10 diperoleh nilai $\mathrm{p}$ value sebesar $0,057>0,05$, artinya tidak terdapat perbandingan hasil penjualan pada tahun 2015 baik dengan promosi maupun tanpa promosi. Hal tersebut diperkuat dengan selisih rata-rata perolehan hasil penjualan yang relative rendah yaitu sebesar 22,716,666 sebelum menggunakan promosi dan 24,300,000 setelah menggunakan promosi.

Tabel 11. Perbandingan Hasil Penjualan dengan Promosi dan Tanpa Promosi Tahun 2016

\begin{tabular}{cllcc}
\hline \multicolumn{2}{c}{ Variabel } & N & Mean & P-value \\
\hline Hasil Penjualan & Sebelum $*$ & 12 & $23,591,666$ & 0,000 \\
Tahun 2016 & Sesudah & & $28,008,333$ & \\
\hline
\end{tabular}

Berdasarkan tabel 11 diperoleh nilai $\mathrm{p}$ value sebesar $0,000<0,05$, hal ini menunjukkan adanya perbandingan hasil penjualan yang signifikan pada tahun 2016 sebelum menggunakan promosi dan sesudah menggunakan promosi. Hal tersebut diperkuat dengan rata-rata perolehan hasil penjualan sebelum menggunakan promosi sebesar 23,591,666 meningkat sebesar 28,008,333 setelah menggunakan promosi.

Tabel 12. Perbandingan Hasil Penjualan dengan Promosi dan Tanpa Promosi Tahun 2017

\begin{tabular}{cllcc}
\hline \multicolumn{2}{c}{ Variabel } & N & Mean & P-value \\
\hline Hasil Penjualan & Sebelum * & 12 & $24,841,666$ & 0,000 \\
Tahun 2017 & Sesudah & & $30,425,000$ & \\
\hline
\end{tabular}


Tabel 12 diperoleh nilai $\mathrm{p}$ value sebesar $0,000<0,05$, hal ini menunjukkan adanya perbandingan hasil penjualan yang signifikan sebelum menggunakan promosi dan sesudah menggunakan promosi pada tahun 2017. Hal tersebut diperkuat dengan rata-rata perolehan hasil penjualan sebelum menggunakan promosi sebesar 24,841,666 meningkat sebesar 30,425,000 setelah menggunakan promosi.

\section{Kesimpulan}

Jumlah penjualan tahun 2013 sampai dengan 2017 mengalami peningkatan sesudah memakai media promosi radio. Peningkatan penjualan yang paling tinggi terjadi pada bulan Januari tahun 2017 dari Rp. 21.000.000 menjadi Rp. 33.000.000. Jumlah total peningkatan penjualan ritel selama 5 tahun setelah menggunakan media promosi seebesar Rp. 36.500.000. Hasil penelitian menunjukan perbandingan pemakaian media promosi selama 5 tahun ratarata hasil penjualan selama 5 tahun menggunakan promosi sebesar 24,800,000 lebih besar dibandingkan sebelum menggunakan promosi sebesar 22,483,333. Artinya media promosi dapat meningkatkan hasil penjualan. Perubahan pertahuan dari 2013-2017 yang terjadi perbedaaan singnifikan sebelum dan seudah menggunakan promosi yaitu tahun 2016 dan 2017 sedangkan tahun 2013- tahun 2015 sebelum dan seudah menggunakan promosi tidak terdapat perbedaan yang signifikan. Media handphone dan media koran merupakan alat promosi yang tepat guna meningkatkan hasil penjualan. Saran penelitian selanjutnya yaitu menambahakan analisis media promosi tidak hanya melalui medi handphone, koran, brosur radio sehingga dapat dianalisis lebih lanjut.

\section{Daftar Pustaka}

Amaliati, S. D. (2017). Tinjauan Atas Implementasi Siklus Pembelian Dan Pembayaran Barang Import. Jurnal STEI Ekonomi, 26(01), 36-58. https://doi.org/10.36406/jemi.v26i01.196

Cahyadin, M., Sutomo, \& Ratwianigsih, L. (2017). Industri Perdagangan Di Indonesia: Perkembangan Dan Kinerja. Jiep, 17(2), 78-88.

Devy, P. I. (2017). Perubahan Perilaku Konsumtif Masyarakat Dari Pasar Tradisional Ke Pasar Modern. Asketik, 1(1), 35-43. https://doi.org/10.30762/ask.v1i1.409

Falah, S., \& Suparmin, S. (2016). Hubungan Motivasi Belajar Dan Perilaku Hidup Sehat Dengan Prestasi Belajar Kejuruan Otomotif Kelas Xi Program Keahlian Teknik Otomotif Smk Muhammadiyah Imogiri Bantul Tahun Ajaran 2014/2015. Taman Vokasi, 4(2), 236. https://doi.org/10.30738/jtvok.v4i2.508

Hedynata, M. L., \& Radianto, W. E. D. (2016). Strategi Promosi Dalam Meningkatkan Penjualan Luscious Chocolate Potato Snack. Strategi Promosi, 1(April), 1-10.

Inas Fahmiyah, M. I. G. (2019). Konsep Waralaba Perspektif Ekonomi Islam Inas Fahmiyah 1 , Moh. Idil Ghufron 2. 3(1), 130-147.

Iskandar, I. (2017). Pengaruh Kewirausahaan dan Peluang Pasar terhadap Kinerja Usaha Perdagangan Mikro Kecil dan Menengah di Kecamatan Peureulak Kota Kabupaten Aceh Timur. Jurnal Samudra Ekonomi Dan Bisnis, 8(1), 611-618. 
https://doi.org/10.33059/jseb.v8i1.200

Malinda, Y. (2016). Analisis Pemasaran Dan Kebijakan Perdagangan Internasional Di Sumatera Barat. Economica, 4(2), 277-295. https://doi.org/10.22202/economica.v4i2.632

Mukaram, M., \& Sarah, I. S. (2017). Analisis Faktor Lingkungan Bisnis Ritel Berbasis Swalayan Pada Lab. Bisnis. Jurnal Riset Bisnis Dan Investasi, 2(3), 85. https://doi.org/10.35697/jrbi.v2i3.95

Pagiu, C., Pundissing, R., \& Tahirs, J. P. (2019). Strategi pemasaran PT. Pengadaian cabang Tallunglipu Toraja Utara.JEMMA (Journal of Economic, Management and Accounting), 2(2), 68-74

Saputra, K. E. A., Suwena, K. R., \& Tripalupi, L. E. (2016). Studi komparatif prestasi belajar mahasiswa jurusan pendidikan ekonomi ditinjau dari jalur penerimaan mahasiswa baru tahun 2011. Jurnal Pendidikan Ekonomi Undiksha, 6(1).

T Kasim, K. (2014). Analisis Komparatif Selera Konsumen Perkotaan Gendongan Bayi Merk Badawi Traso Warna Merah. 4(1), 61-70.

Utami, N. S. (2018). Analisa Kinerja Sektor Ritel Indonesia. Ecopreneur, 1(1), 43-48.

Yusuf, M., \& Rangkuty, D. M. (2019). Analisis Neraca Perdagangan Indonesia-India Periode 2013-2018. Penelitian Medan Agama, 10(1), 56-68. 